\title{
Phlebotomine sandflies in a focus of dermal leishmaniasis in the eastern region of the Brazilian State of Santa Catarina - preliminary results (Diptera: Psychodidae)
}

\author{
Flebotomíneos num foco de leishmaniose tegumentar na região leste do \\ Estado de Santa Catarina - resultados preliminares (Diptera: Psychodidae)
}

\author{
Carlos Brisola Marcondes ${ }^{1}$, Maria Bernadete E. Conceiçãa ${ }^{2}$, \\ Maria Graça T. Portes ${ }^{3}$ and Bento P. Simão ${ }^{2}$
}

\begin{abstract}
Due to the occurrence of cases of dermal leishmaniasis in the Municipality of Piçarras, in the East of the Brazilian State of Santa Catarina, collections of Phlebotomine sandflies by the use of CDC-like light traps were developed near the houses of the patients. Three species (Lutzomyia neivai, Lu. fischeri and Lu. ayrozai) were collected. Lu. neivai was predominant near the houses, and Lu. ayrozai was collected in a secondary forest in a nearby municipality (Navegantes). The novelty of this focus, the most southern one in the East of Brazil, underscores the need for more complete studies on the sandfly fauna.
\end{abstract}

Key-words: Phlebotominae. Dermal leishmaniasis. Santa Catarina. Brazil. Epidemiology.

\section{RESUM0}

Devido à ocorrência de casos de leishmaniose tegumentar no Município de Piçarras, na parte leste do Estado de Santa Catarina, Brasil, foram realizadas coletas com armadilhas luminosas tipo CDC nas proximidades de casas de pacientes. Três espécies ( Lutzomyia neivai, Lu. fischeri e Lu. ayrozai) estavam representadas nas coletas. Lu. neivai foi predominante e Lu. ayrozai foi coletada em mata secundária. 0 ineditismo deste foco, o mais meridional no leste do Brasil, indica serem necessários estudos mais detalhados da fauna de flebotomíneos na área.

Palavras-chaves: Phlebotominae. Leishmaniose tegumentar. Santa Catarina. Brasil. Epidemiologia.

Dermal leishmaniasis was previously referred in the State of Santa Catarina ${ }^{15}$, caused by Leishmania braziliensis and $\mathrm{L}$ amazonensis ${ }^{6}$ ( $\mathrm{L}$ is utilized here as an abbreviation of Leishmania, to differentiate Lu. from Lutzomyia). This disease has been reported in the West of this State, and some human cases of dermal leishmaniasis have been observed in the Municipality of Piçarras, in the eastern coast of the state ${ }^{18}$. A survey by Montenegro reaction indicated high prevalence of infection (12.1\%) in humans and in dogs (17.1\%) in a locality in Piçarras (Nossa Senhora da Conceição), showing active transmission of parasites ${ }^{19}$.

The fauna of Phlebotomine sand flies in Santa Catarina is largely unknown. Lu. neivai was referred ${ }^{1216}$. Twelve species were listed for the state ${ }^{1}$. Although the fauna in the western foci of Santa Catarina has been studied, nothing is known about the insects of the newly detected focus in the coastal region. The only study in the eastern region of the southern states was developed in a primary forest in Morretes (Paraná) ${ }^{12}$, besides some studies a long time ago in the East of Rio Grande do Sul, in which Lu. neivai (as Phlebotomus intermedius) and Lu. fischeri were reported ${ }^{14}$.

Collections of insects were developed in the focus of dermal leishmaniasis situated at the Municipality of Piçarras, mostly near the houses where cases of dermal leishmaniasis had been reported, and in a secondary forest in the Municipality of Navegantes.

\footnotetext{
1. Departamento de Microbiologia e Parasitologia do Centro de Ciências Biológicas da Universidade Federal de Santa Catarina, Florianópolis, SC. 2. Coordenação da Fundação Nacional de Saúde/NENSC, Florianópolis, SC. 3. Fundação Nacional de Saúde/NENSC, Joinvile, SC.

Address to: Dr. Carlos Brisola Marcondes. MIP/CCB/UFSC. Campus Universitário - Trindade - Caixa Postal 476, 88040-900 Florianópolis, SC.

e-mail: cbrisola@mbox1.ufsc.br

Recebido para publicação em 7/5/2004

Aceito em 8/4/2005
} 
Collections were taken in March and April 2000 in the locality of Nossa Senhora da Conceição ( $26^{\circ} 45^{\prime} 50^{\prime \prime}$ S 4841'19” W, 49m a. s. l.), in the Municipality of Piçarras. This locality is suburban, and all houses are situated at a maximum of $200 \mathrm{~m}$ from a main street, which continues in a $3 \mathrm{~km}$ road and starts and ends on the BR-101 highway. The distance between BR-101 and the coast is about $600 \mathrm{~m}$. There is a little secondary vegetation, including some banana and other fruit trees; residual secondary forests are very small and far from houses. Some collections were also developed in an area of secondary vegetation (Escalvado) in the nearby municipality of Navegantes (26 $53^{\prime} 56^{\prime \prime}$ S 48039'15" W). Six collections were done using Shannon traps ${ }^{17}$ with a lamp, and CDClike miniature light traps, with 6.6 V rechargeable batteries ${ }^{1320}$ were utilized, in 30 trap/nights.

Collections with Shannon trap were negative. Sandflies collected by miniature light traps were identified as belonging to one of three species (Table 1). Lu. neivai was the predominant species, and Lu. ayrozai was collected only in the secondary forest. Since this is a preliminary study, the mean quantities per collection, which were very low, are not given.

Lu. neivai, although not fulfilling all the requirements to be considered a vector of Leishmania to man ${ }^{7}$, has been strongly suspected as a vector of these protozoa. In the Ribeira Valley, at the São Paulo State, where both species of the Lu. intermedia complex occur ${ }^{11}$, Lu. intermedia s. l. has been incriminated as a vector of $\mathrm{L}$ braziliensis near the domiciles ${ }^{4}$. Lu. neivai is also the predominant species in the houses in the North of Paraná State, and some modifications have been proposed to reduce the risk for the population ${ }^{21}$. In the present preliminary study, Lu. neivai is the predominant species near the houses, where the transmission of the parasites is probably occurring. The vegetation in the region was very modified, and this modification probably facilitated the adaptation of this sand fly to the areas near the houses.

$\mathrm{Lu}$. ayrozai has been strongly suspected as a vector of $\mathrm{L}$ naiffi in the Amazon region ${ }^{8}$. Its anthropophily is low in Colombia ${ }^{15}$, but several insects of this species were collected biting man in the Ribeira Valley ${ }^{5}$, and this is the only species that sometimes has bitten man in daylight in a secondary forest in the Island of Santa Catarina (CB Marcondes: unpublished observations). This may indicate some regional variation of the species. Its role in the transmission of $\mathrm{L}$ braziliensis in the region may notbe discarded. However, since there is no evidence of association of cases with the forest, $\mathrm{Lu}$. ayrozai has probably no direct role in the infection of humans. Several species were present in collections from primary forest in Morretes, $300 \mathrm{~km}$ to the North ${ }^{11}$, but that study was much more extensive, and in a more humid and preserved area, which is probably similar to the one occurring originally in Piçarras.

Table 1- Phlebotomine sandflies collected in the localities of Nossa Senhora da Conceição (CO, Município - Piçarras) and Escalvado (ES, Município - Navegantes), State of Santa Catarina, using CDC-like miniature light traps.

\begin{tabular}{|c|c|c|c|c|c|c|c|c|c|c|}
\hline & \multicolumn{9}{|c|}{ Phlebotomine species } & \multirow[b]{3}{*}{ Total } \\
\hline & \multicolumn{3}{|c|}{ Lu. neivai } & \multicolumn{3}{|c|}{ Lu. fischeri } & \multicolumn{3}{|c|}{ Lu. ayrozai } & \\
\hline & $\bar{F}$ & $\mathrm{M}$ & Total & $\mathrm{F}$ & $\mathrm{M}$ & Total & $\mathrm{F}$ & M & Total & \\
\hline CO- house of infected boys & 1 & 1 & 2 & 0 & 0 & 0 & 0 & 0 & 0 & 2 \\
\hline ES- border of the forest & 0 & 0 & 0 & 0 & 0 & 0 & 1 & 0 & 1 & 1 \\
\hline ES- border of the forest & 0 & 1 & 1 & 0 & 0 & 0 & 0 & 0 & 0 & 1 \\
\hline CO- neighborhood of infected boys' house & 0 & 1 & 1 & 0 & 0 & 0 & 0 & 0 & 0 & 1 \\
\hline $\mathrm{CO}$ - end of the road- in the chicken roost & 8 & 9 & 17 & 0 & 0 & 0 & 0 & 0 & 0 & 17 \\
\hline ES-in the forest & 0 & 0 & 0 & 1 & 0 & 1 & 0 & 0 & 0 & 1 \\
\hline CO- neighborhood of boys' house & 0 & 1 & 1 & 0 & 0 & 0 & 0 & 0 & 0 & 1 \\
\hline CO- under tree, near a chicken roost- extreme of road & 0 & 4 & 4 & 0 & 0 & 0 & 0 & 0 & 0 & 4 \\
\hline CO- pigsty & 1 & 2 & 3 & 0 & 0 & 0 & 0 & 0 & 0 & 3 \\
\hline CO- near pigsty & 2 & 3 & 5 & 0 & 0 & 0 & 0 & 0 & 0 & 5 \\
\hline CO- near banana trees & 0 & 0 & 0 & 1 & 0 & 1 & 0 & 0 & 0 & 1 \\
\hline CO-near house & 1 & 1 & 2 & 0 & 0 & 0 & 0 & 0 & 0 & 2 \\
\hline CO-near house & 1 & 0 & 1 & 0 & 0 & 0 & 0 & 0 & 0 & 1 \\
\hline CO-near house & 1 & 0 & 1 & 0 & 0 & 0 & 0 & 0 & 0 & 1 \\
\hline CO-near house and birds' cage & 0 & 1 & 1 & 0 & 0 & 0 & 0 & 0 & 0 & 1 \\
\hline CO-near house & 0 & 1 & 1 & 0 & 0 & 0 & 0 & 0 & 0 & 1 \\
\hline CO-near house & 2 & 1 & 3 & 0 & 0 & 0 & 0 & 0 & 0 & 3 \\
\hline $\mathrm{CO}$ - end of road- in the chicken roost & 1 & 2 & 3 & 0 & 0 & 0 & 0 & 0 & 0 & 3 \\
\hline CO- in the forest & 0 & 1 & 1 & 0 & 0 & 0 & 0 & 0 & 0 & 1 \\
\hline $\mathrm{CO}$ - end of road- under tree- near a chicken roost & 2 & 1 & 3 & 0 & 0 & 0 & 1 & 1 & 2 & 5 \\
\hline CO- end of road- under tree- in the chicken roost & 0 & 2 & 2 & 0 & 0 & 0 & 0 & 0 & 0 & 2 \\
\hline $\mathrm{CO}$ - in a chicken roost & 3 & 2 & 5 & 0 & 0 & 0 & 0 & 0 & 0 & 5 \\
\hline CO -under a tree ( avocado-pear) & 5 & 6 & 11 & 0 & 0 & 0 & 0 & 0 & 0 & 11 \\
\hline CO- in a chicken roost & 0 & 1 & 1 & 0 & 0 & 0 & 0 & 0 & 0 & 1 \\
\hline CO- in the forest, near a house & 0 & 2 & 2 & 0 & 0 & 0 & 0 & 0 & 0 & 2 \\
\hline CO- near a house & 4 & 7 & 11 & 0 & 0 & 0 & 0 & 0 & 0 & 11 \\
\hline Total & 32 & 50 & 82 & 2 & 0 & 2 & 2 & 1 & 3 & 87 \\
\hline
\end{tabular}

M- males; F- females. 
Lu. migonei was not yet found on this region, but since it is a common species in Forianópolis (CB Marcondes: unpublished results) and Morretes ${ }^{11}$, it will certainly be obtained in future more extensive studies. However, its absence in this study may indicate that it is a rare species in Piçarras.

Transmission of Leishmania to man depends on several factors, and there are several kinds of cycle in the differentareas 9 . Other studies, preferably including the extensive collection of sand flies and the analysis of its natural infection rate, must be developed in the area.

The alleged presence of Lu. intermedia in the State of Santa Catarina ${ }^{1}$ is probably based on the non-acceptance of the differentiation between the species of the Lu. intermedia complex ${ }^{211}$ or in reports published before this proposal of resurrection of Lu. neivai ${ }^{31416}$. Since no justification has been published for this non-acceptance, it is better to consider the species in the southern Brazilian states and in other countries as Lu. neivai. No study in this region have obtained Lu. intermedia S.S., as defined previously ${ }^{2}$.

\section{REFERENCES}

1. Aguiar GM. Distribuição regional e hábitats das espécies de flebotomíneos do Brasil. In: Rangel EF, Lainson R (orgs) Flebotomíneos do Brasil. Editora da Fundação Oswaldo Cruz, Rio de Janeiro, p.205-255, 2003.

2. Andrade-Filho JD, Galati EAB, Falcão AL. Redescription of Nyssomyia intermedia (Lutz \& Neiva, 1912) and Nyssomyia neivai (Pinto, 1926) Diptera: Psychodidae). Memórias Instituto Oswaldo Cruz 98:1059-1065, 2004.

3. Di Primio R. Os flebótomos do litoral do Rio Grande do Sul. Arquivos Riograndenses Medicina 16:475-482, 1937.

4. Gomes AC. Sand fly vectorial ecology in the State of São Paulo. Memórias do Instituto Oswaldo Cruz 89:457-460, 1994.

5. Gomes AC, Galati EAB. Aspectos ecológicos da leishmaniose tegumentar americana. 7- Capacidade vetorial flebotomínea em ambiente florestal primário do sistema da Serra do Mar, região do Vale do Ribeira, Estado de São Paulo, Brasil. Revista Saúde Pública 23:136-142, 1989.

6. Grisard E, Steindel M, Shaw JJ, Ishikawa EAY, Carvalho-Pinto CJ, EgerMangrich I, Toma HK, Lima JH, Romanha AJ, Campbell DA. Characterization of Leishmania sp strains isolated from autochthonous cases of human cutaneous leishmaniasis in Santa Catarina State, Southern Brazil. Acta Tropica 74:89-93, 2000.
7. Killick-Kendrick R. Phlebotomine vectors of the leishmaniasis: a review. Medical and Veterinary Entomology 4:1-24, 1990.

8. Lainson R, Shaw JJ, Silveira FT, Braga RR, Ishikawa EAY. Cutaneous leishmaniasis of man due to Leishmania (Viannia) naiffi Lainson \& Shaw, 1989. Annales Parasasitologie Humaine Comparée 65:282-284, 1990.

9. Lainson R, Shaw JJ, Silveira FT, Souza AAA, Braga RR, Ishikawa EAY. The dermal leishmaniases of Brazil, with special reference to the ecoepidemiology of the disease in Amazonia. Memórias Instituto Oswaldo Cruz 89:435-443, 1994.

10. Marcondes CB. A redescription of Lutzomyia (Nyssomyia) intermedia (Lutz \& Neiva, 1912) , and resurrection of L neivai (Pinto, 1926) (Diptera, Psychodidae, Phlebotominae). Memórias do Instituto Oswaldo Cruz 91:457-462, 1996.

11. Marcondes CB, Lozovei AL, Vilela JH. Distribuição geográfica de flebotomíneos do complexo Lutzomyia intermedia (Lutz \& Neiva, 1912) (Diptera, Psychodidae). Revista Sociedade Brasileira Medicina Tropical 31:51-58, 1998.

12. Marcondes CB, Santos-Neto LG, Lozovei AL. Ecology of Phlebotomine sandflies (Diptera, Psychodidae) in Brazilian Atlantic forest. Revista Sociedade Brasileira Medicina Tropical 34:255-260, 2001.

13. Natal D, Marucci D, Reis IM, Galati EAB. Modificação da armadilha CDC com testes para coletas de flebotomíneos (Diptera). Revista Brasileira Entomologia 35:697-700, 1991.

14. Pinto C. Pesquisas sobre parasitologia humana e animal no Rio Grande do Sul. Arquivos do Departamento de Estadual de Saúde do Rio Grande do Sul 2:73-91, 1941.

15. Porter CH, Defoliart GR. The man-biting activity of phlebotomine sand flies (Diptera: Psychodidae) in a tropical wet forest environment in Colombia. Arquivos Zoologia 30:85-158, 1981.

16. São Thiago PT, Guida V. Leishmaniose tegumentar no oeste do Estado de Santa Catarina, Brasil. Revista Sociedade Brasileira Medicina Tropical 23:201-203, 1990.

17. Shannon RC. Methods for collecting and feeding mosquitoes in jungle yellow fever. American Journal Tropical Medicine 19:131-140, 1939.

18. Steindel M, Lima JH, Marcondes CB, Luz AC, Mangrich IE, Grisard EC. Autochthonous cutaneous leishmaniasis due to Leishmania braziliensis in the Municipality of Piçarras, north-eastern region of the State of Santa Catarina, Brazil. Memórias Instituto Oswaldo Cruz 93( supl) :121, 1998.

19. Steindel M, Lima HC, Rangel RCT, Koerich LC, Grisard EC. Report on the southernmost foci of cutaneous leishmaniasis in Brazil. International Congress Tropical Medicine Malaria, Cartagena. p. 115-115, 2000.

20. Sudia WD, Chamberlain RW. Battery-operated light trap, an improved model. Mosquito News 22:126-129, 1962.

21. Teodoro U, Silveira TG, Santos DR, Santos ES, Santos AR, Oliveira O, Kuhl JB, Alberton D. Influência da reorganização, da limpeza do peridomicílio e a da desinsetização de edificações na densidade populacional de flebotomíneos no Município de Doutor Camargo, Estado do Paraná, Brasil. Cadernos Saúde Pública 19:1801-1813, 2003. 